\title{
Assessment on fishery sustainability in Inle wetland, Nyaung Shwe township, southern Shan state
}

\begin{abstract}
The six indicators were used to analyze for sustainable fishery management in Inle wetland and grouped into four components categories-ecological, economic, community and institutional. A total of 41 fish species, among them 13 endemic and 16 ornamental fishes were found. The value of DO was slightly below the WHO standard in all study sites. The concentration of phosphate was relatively high, probably because of originated from domestic and agriculture uses. Inle water is under treated by contamination of fertilizers and pesticides used in floating cultivations in and around the Lake and also affected by other anthropogenic activities. The water of Inle Lake found to be hard water lake. Its high calcium can be attributed to the lime stone of Shan Plateau. The fish species population abundance is currently low probably because of changes water quality and decreased clarity. Thus, there is an urgent need to uplift the status of the fishermen and also to safeguard the sustainability of array of indigenous, endemic and ornamental fish species that enjoy the ecofriendly nature of Inle water. Moreover, there is a need to maintain the Inle Lake to be environmentally friendly for the aquatic fauna and flora to thrive.
\end{abstract}

Volume 3 Issue 5 - 2018

\author{
Seint Seint Win,' Khin Maung Gyi, ${ }^{2}$ Mie Mie \\ Sein $^{3}$ \\ 'Department of Zoology, Kyaing Tong University, Myanmar \\ ${ }^{2}$ Head of Zoology Department, Mandalay University of Distance \\ Education, Myanmar \\ ${ }^{3}$ Mawlamyine University, Myanmar
}

Correspondence: Seint Seint Win, Lecturer, Department of Zoology, Kyaingtong University, Eastern Shan State, Myanmar, Email: seintseintwin22@gmail.com

Received: August 13, 2018| Published: September 20, 2018

Keywords: indicators, fish, sustainable fishery, inle Lake

\section{Introduction}

Inle Lake is located on the Shan plateau in the Southern Shan State of Myanmar. It is the largest Lake in Shan State. The elevation of the lake is $890 \mathrm{~m}$ above sea level to offer splendid view. Moreover, this is the important freshwater resource for local residents. The people who live in Inle wetland are called "intha". "In" stands for "lake", while "tha" means "people" in Myanmar. Thus, the name literally means "lake people". ${ }^{1-3}$ In the Inle Lake, the presence of unique aquatic organisms adapted to water hyacinth, reeds and hornwort. Inle Lake is one of the most important fishing grounds for the inland fisheries sector. As the second largest lake in Myanmar, it covers a total area of approximately 6220 ha with a catchment area of 1630 ha. ${ }^{4}$ Wetlands are vital for human survival. They are among the world's most productive environment; cradles of biodiversity that provide the water and productivity upon which countless species of plants and animals depend for survival. ${ }^{5}$

Inle Lake is a well-known tourist attraction in Southern Shan State for natural scenic beauty, leg rowing fishermen and diverse wetland ecosystem. Inle Wetland Wildlife Sanctuary (IWWS) was established by Forest Department in 1985. In 2003, Inle Lake was designated by ASEAN Heritage Park and Myanmar's first Biosphere Reserve under UNESCO's Man and the Biosphere (MAB) programme at the UNESCO Head-quarter in Paris in June 2015. The Lake provides the livelihood for about 460 fisher families and many "floating garden" agriculturists, and service provider such as boatmen. ${ }^{6}$ The unregulated usage of pesticide affects the transparency of the lake water. These changes have reduced the fishermen's catch, especially that of species unique to the lake. ${ }^{7}$ There are many endemic species found in Inle Lake. Now, Inle is suffering from the environmental effects of increased human population and rapid growth of agriculture.

The present study has been undertaken with the following objectives,
1. To investigate the water quality and catching rate of fishes in Inle wetland area

2. To assess the fishery in Inle wetland base on sustainable indicators

\section{Materials and methods}

Study area and site: Inle Lake is located on the Shan plateau in the Southern Shan State of Myanmar. It lies between the 20 36' $07^{\prime \prime}$ N and $96^{\circ} 55^{\prime} 38^{\prime \prime} \mathrm{E},(2950$ feet) $900 \mathrm{~m}$ above sea level. The length of the Inle Lake is about $21 \mathrm{~km}$ from north to south and a width of $8 \mathrm{~km}$ from east to west. The study sites are Site I (Innla`e Bo Ta`e), Site II (Kay La), Site III (Nam Pan) and Site IV (Kon Kyeng).

Study period: The present study was conducted from March 2016 to February 2018.

\section{Data collection and water sample}

The sampling of fish was undertaken four sampling sites of the study area. For determining of physico-chemical properties of water from the four study sites, one liter of surface water was collected from different sampling sites during morning time 7:00 AM. The collection was made every season. Water analysis for physico-chemical parameters was carried out in the chemical lab of Research Unit; Department of Fisheries (DoF), Yangon for tested and analyzed the water quality by using standard analytical method (WHO) ${ }^{8,9}$

The surface water temperature was measured by mercury thermometer. Different parameters such as $\mathrm{pH}$, turbidity, DO, BOD, total hardness, phosphate and calcium were analyzed.

Data analysis: The catch per unit of fishing effort (CPUE) in the basic form can be defined as the total catch divided by the total fishing effort in a given period, and followed after Gulland. ${ }^{10}$

$U=C / F$ Where, $U=$ CPUE, $C=$ the total catch, $F=$ the total fishing effort 


\section{Collection of the specimens}

Collection of the specimens was made once per month for all four sampling sites with the help of fishermen. Diverse fishing gears used (depending on targeted species and size) was mainly gill nets (TannPike) $(25.4 \mathrm{~mm}-101.6 \mathrm{~mm})$ and small traps (Myone Te) in different sampling sites. Monthly data of fish catches were recorded. Fishermen set the gillnets at different depth in the water surface, ranging from $30.48 \mathrm{~cm}$ ( 1 feet) below the water surface in hot season and $121.92 \mathrm{~cm}$
(4 feet) in raining season. The morphological characters of the collected fish species were recorded and photographs were taken in fresh condition soon after the fish were caught.

\section{Identification of the collected fish species}

Identification of the collected species was followed by Talwar, P.K. and Jhingran, A.G (Figure 1). ${ }^{11-13}$

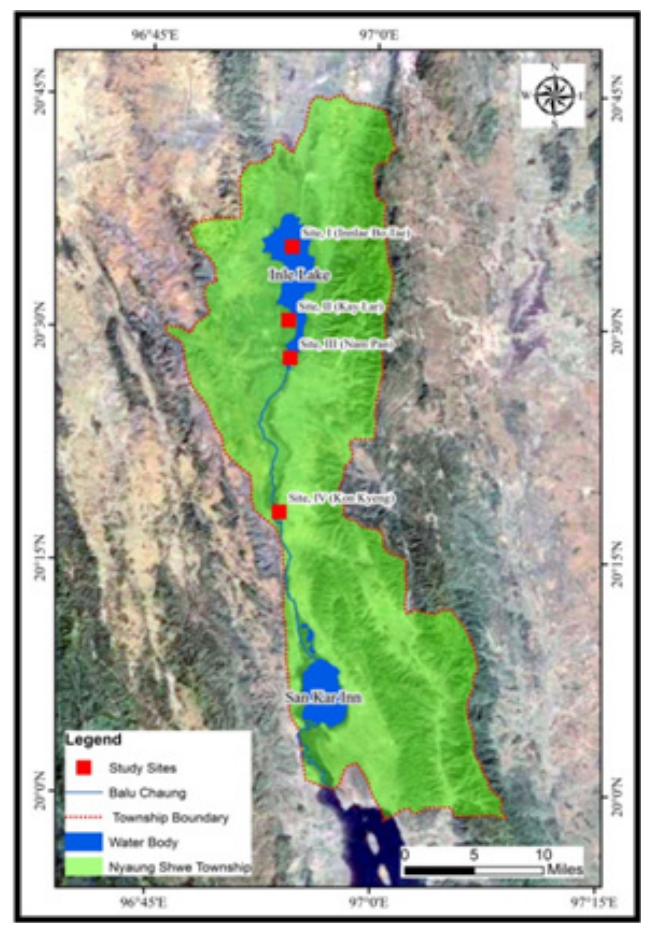

Figure I Map of Inle Lake.

\section{Results}

Sustainable fishery in Inle Lake was conducted on the basis of the results of six indicators. They are (1) water quality (2) catch per unit effort, CPUE (3) availability of fish species (4) productivity (5) community participation and (6) control of illegal fishing gear. The data collection in Inle Lake and grouped into four categories ecology, economic, community and policy and institution (Table 2). A total of 41 species confined to 34 genera, 17 families and six orders
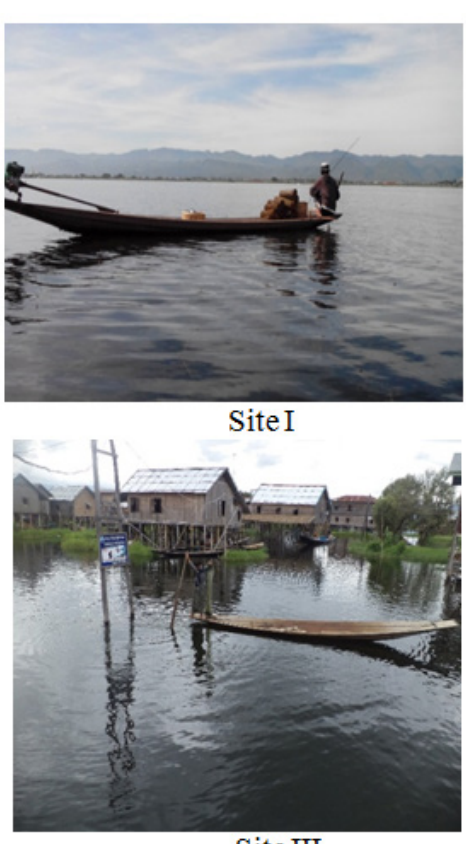

Site III

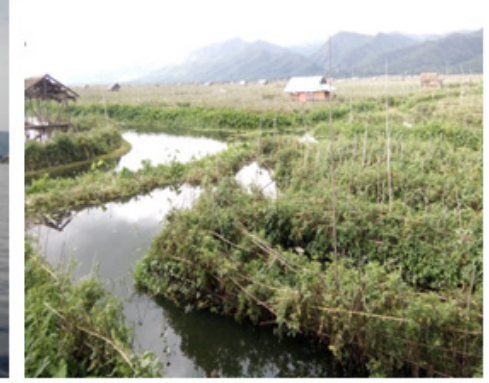

Site II

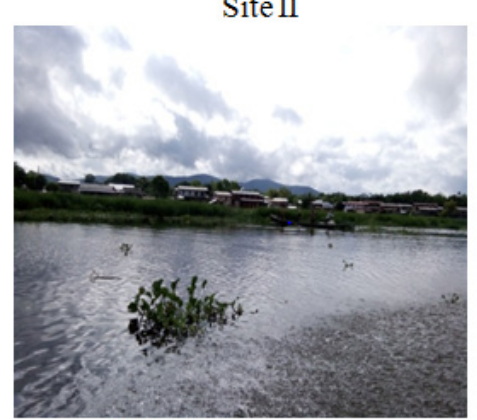

Site IV

Table I Status of collected fish species from Inle wetland

\begin{tabular}{lllll}
\hline & \multicolumn{2}{l}{ Status } & & \\
\cline { 2 - 5 } Collected fish species & Introduce & Native & Endemic & Ornamental \\
\cline { 2 - 5 } & species & Species & species & species \\
\hline Notopterus notopterus & - & $\checkmark$ & - & - \\
Cyprinus carpio & $\checkmark$ & - & - & - \\
C. intha & - & - & $\checkmark$ & - \\
Gymnostomus horai & - & - & $\checkmark$ & - \\
Ctenopharyngodon idella & $\checkmark$ & - & - & - \\
Labeo rohita & $\checkmark$ & - & - & - \\
Neolissochilus nigrovittatus & - & - & $\checkmark$ & $\checkmark$ \\
\hline
\end{tabular}

were recorded and the status of collected fish species was presented (Table 1). Among them, the catch of 12 species increased, whereas those of 22 species decreased and the other species remained stable. The parameters of water quality were collected from all study sites in Inle (Table 3). The local authorities (Department of Fishery) control the illegal fishing gear, i.e. fishing with battery shocks and small mesh size nets. Some fishermen use illegal gear. In Inle Lake, the law prohibits fishing in the breeding and spawning period (Figure 2). 
Table continued.

\begin{tabular}{|c|c|c|c|c|}
\hline \multirow{2}{*}{$\begin{array}{l}\text { Collected fish species } \\
\text { Pethia stoliczkana }\end{array}$} & \multicolumn{4}{|c|}{ Status } \\
\hline & - & $\checkmark$ & - & $\checkmark$ \\
\hline Puntius sarana orphoides & - & $\checkmark$ & - & - \\
\hline Poropuntius schanicus & - & - & $\checkmark$ & - \\
\hline Puntius sophore & $\checkmark$ & - & - & - \\
\hline P.ticto & - & $\checkmark$ & - & \\
\hline Barbonymus gonionotus & $\checkmark$ & - & - & - \\
\hline Sawbwa reaplendens & - & - & $\checkmark$ & $\checkmark$ \\
\hline Inlecypris auropurpureus & - & - & $\checkmark$ & $\checkmark$ \\
\hline Celestichthys erythromicron & - & - & $\checkmark$ & $\checkmark$ \\
\hline Esomus danrica & $\checkmark$ & - & - & $\checkmark$ \\
\hline Microrasbora rubescens & - & - & $\checkmark$ & $\checkmark$ \\
\hline Garra gravelyi & - & $\checkmark$ & - & - \\
\hline Petruichthys brevis & - & - & $\checkmark$ & $\checkmark$ \\
\hline Physoschistura rivulicola & - & $\checkmark$ & - & $\checkmark$ \\
\hline Lepidocephalichthys berdmorei & - & $\checkmark$ & - & $\checkmark$ \\
\hline Pterocrtptis burmanensis & - & - & $\checkmark$ & - \\
\hline Clarias batrachus & - & $\checkmark$ & - & - \\
\hline C. gariepinus & $\checkmark$ & - & - & - \\
\hline Heteropneustes fossilis & $\checkmark$ & - & - & - \\
\hline Poecilia reticulata & $\checkmark$ & - & - & $\checkmark$ \\
\hline Monopterus javanensis & - & $\checkmark$ & - & - \\
\hline M. cuchia & - & $\checkmark$ & - & - \\
\hline Mastacembelus caudiocellatus & - & - & $\checkmark$ & $\checkmark$ \\
\hline M. oatesii & - & - & $\checkmark$ & - \\
\hline Chaudhuria caudata & - & $\checkmark$ & - & - \\
\hline Parambassis lala & $\checkmark$ & - & - & $\checkmark$ \\
\hline P. ranga & $\checkmark$ & - & - & - \\
\hline Oreochromis niloticus & $P$ & - & - & - \\
\hline Glossogobius giuris & $\checkmark$ & - & - & - \\
\hline Trichopodus pectoralis & $\checkmark$ & - & - & - \\
\hline Trichogaster labiosa & $\checkmark$ & - & - & $\checkmark$ \\
\hline Anabas testudineus & $\checkmark$ & - & - & - \\
\hline Channa striata & - & $\checkmark$ & - & - \\
\hline C. harcourtbutleri & - & - & $\checkmark$ & $\checkmark$ \\
\hline Total fish Species & 16 & 12 & 13 & 16 \\
\hline
\end{tabular}


Table 2 Sustainability components and indicators employed in Inle Lake

\begin{tabular}{|c|c|c|}
\hline $\begin{array}{l}\text { Sustainability } \\
\text { components }\end{array}$ & Indicators & Operational Definition and Units of Measurement \\
\hline \multirow{3}{*}{ Ecology } & $\begin{array}{l}\text { I. Catch per unit effort } \\
\text { (CPUE) }\end{array}$ & $\begin{array}{l}\text { Catch per unit effort by gill nets and small traps } \\
\text {-Individual/day/unit of fishing gear }\end{array}$ \\
\hline & 2. Water quality & $\begin{array}{l}\text { - Standard classification level of water quality from the Department of Fisheries (DoF), } \\
\text { Yangon } \\
\text { - pH ,DO, BOD, total hardness, phosphate etc. }\end{array}$ \\
\hline & 3.Availability of fish species & $\begin{array}{l}\text {-Procurement of fish by fishermen } \\
\text {-Number of species and categories of fish }\end{array}$ \\
\hline Economic & 4.Productivity & - Income from fish production \\
\hline Community & 5. Community participation & -Fishermen participant in catchment area of Inle Lake \\
\hline $\begin{array}{l}\text { Policy and } \\
\text { Institutions }\end{array}$ & $\begin{array}{l}\text { 6. Control of illegal fishing } \\
\text { gear }\end{array}$ & -Authorities are ready to control illegal fishing gear, e.g., electro fishing gear \\
\hline
\end{tabular}

Table 3 Seasonal variation of physico-chemical parameters of water from four study sites in Inle Lake

\begin{tabular}{|c|c|c|c|c|c|c|c|c|c|c|c|c|c|c|c|}
\hline \multirow[t]{2}{*}{$\begin{array}{l}\text { Physicochemical } \\
\text { parameters }\end{array}$} & \multicolumn{5}{|l|}{ Hot } & \multicolumn{5}{|c|}{ Rainy } & \multicolumn{5}{|c|}{ Cold } \\
\hline & I & II & III & IV & Mean \pm SD & I & II & III & IV & Mean \pm SD & $\mathbf{I}$ & II & III & IV & Mean $\pm S D$ \\
\hline Temperature $\left({ }^{\circ} \mathrm{C}\right)$ & 29 & 30 & 31 & 29 & $29.75 \pm 0.96$ & 26 & 27 & 27 & 27 & $26.75 \pm 0.5$ & 23 & 24 & 25 & 20 & $23 \pm 2.16$ \\
\hline Water Depth (m) & 1.27 & 1.22 & 1.3 & 0.91 & $1.18 \pm 0.18$ & 2.44 & 1.82 & 1.52 & 1.83 & $1.90 \pm 0.39$ & 2.49 & 2.13 & 1.82 & 2.13 & $2.14 \pm 0.27$ \\
\hline $\mathrm{pH}$ & 7.5 & 7 & 7.1 & 7.5 & $7.28 \pm 0.26$ & 7.5 & 7.4 & 7.4 & 7.5 & $7.45 \pm 0.06$ & 7.3 & 6.9 & 7.4 & 7.1 & $7.18 \pm 0.22$ \\
\hline Turbidity(NTU) & 5.12 & 5.12 & 15.2 & 12.5 & $9.49 \pm 5.16$ & 10.6 & 10.55 & 12.98 & 10.34 & $11.12 \pm 1.25$ & 6 & 6 & 6 & 10.2 & $7.05 \pm 2.1$ \\
\hline $\mathrm{DO}(\mathrm{mg} / \mathrm{L})$ & 4 & 4.5 & 4 & 4 & $4.13 \pm 0.25$ & 5 & 5 & 4 & 5 & $4.75 \pm 0.5$ & 3.79 & 3.34 & 4.52 & 3.5 & $3.79 \pm 0.52$ \\
\hline BOD (mg/L) & 2.5 & 3 & 2.5 & 3 & $2.75 \pm 0.29$ & 3.5 & 3.5 & 3 & 3.25 & $3.31 \pm 0.24$ & 8.6 & 6.1 & 6.8 & 2 & $5.88 \pm 2.79$ \\
\hline TotalHardness $\left(\mathrm{CaCo}_{3}\right)$ & 164 & 188 & 188 & 220 & $190 \pm 22.98$ & 230 & 270 & 310 & 240 & $262.5 \pm 35.94$ & 200 & 240 & 200 & 180 & $205 \pm 25.17$ \\
\hline Total Alkalinity(mg/L) & 120 & 144 & 140 & 172 & $144 \pm 21.42$ & 220 & 230 & 200 & 180 & $207.5 \pm 22.17$ & 325 & 325 & 390 & 160 & $300 \pm 98.23$ \\
\hline Phosphate (mg/L) & 0.5 & 0.55 & 0.26 & 0.26 & $0.39 \pm 0.15$ & 0.53 & 0.5 & 0.25 & 0.24 & $0.38 \pm 0.16$ & 0.5 & 0.51 & 0.52 & 0.28 & $0.45 \pm 0.12$ \\
\hline
\end{tabular}

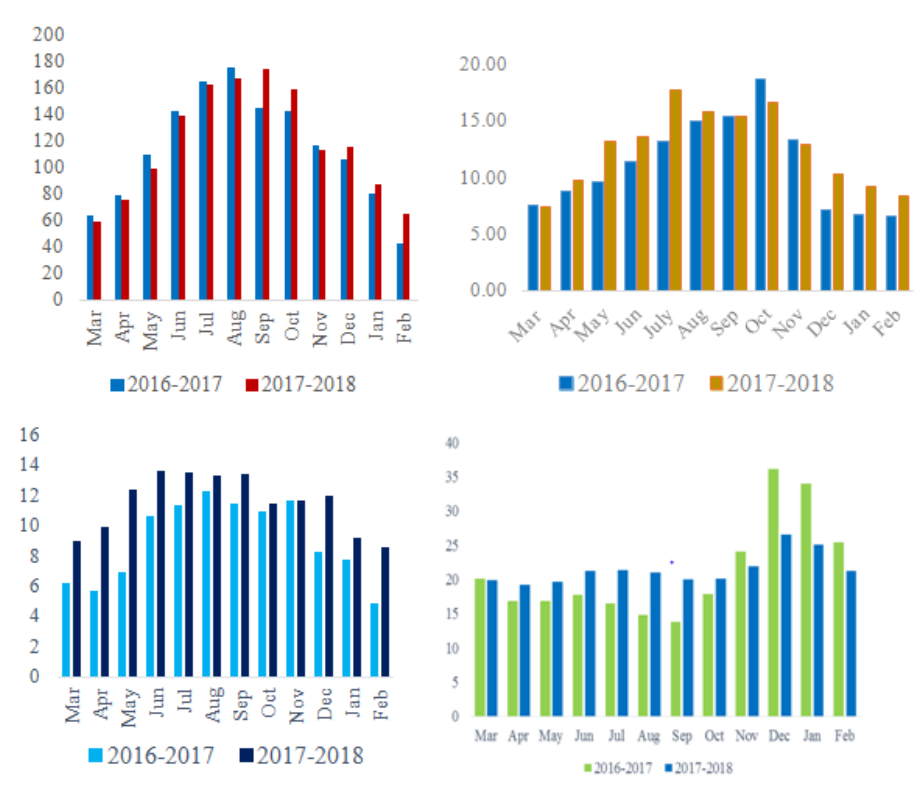

Figure 2 Total number of individuals CPUE (individuals/net) in four study sites of Inle Lake. 


\section{Discussion}

In the present study, the six indicators were used to analyze for sustainable fishery management of Inle Lake. They were included the four sustainability components. The ecological indicators described the physical and biological environmental qualities that provide fishery resources in Inle Lake. They are catch per unit effort (CPUE) by gill nets and small traps, the test of water quality in the lake and the availability of fish species was indicated by fishermen catch in Inle Lake.

A total of 41 available fish species, Notopterus notopterus, Cyprinus intha, Channa striata, Oreochromis niloticus and Monopterus javanensis are more popular marketable fishes. In the study area, 16 species are ornamental and 13 endemic fishes found in Inle wetland. The ornamental fish species are very popular in aquarium fish trade. 12 species of ornamental fishes were found in Inle Lake and 15 species in Hopone Dam, Southern Shan State. ${ }^{14}$

In Site I (Innla`e Bo Ta`e) the water depth was gradually increased from hot season to cold season because it was the open area and fishing ground of Inle Lake. The highest CPUE numbers of fish species was found in Site I because it is the deep water bodies and fishing ground of Inle Lake. The CPUE of marketable fish such as Oreochromis sp. was the highest number in all study sites.

The IUCN ${ }^{15}$ Red List declared the Inle carp as endangered as it had been impacted by the introduction of some Cyprinus species in the lake. The conditions of these threatened species may vary with a result of overfishing due to the market settled demand. Inle Lake has an outstanding endemic fish fauna while non-native species have established in and around the lake. The two endemic species Systomus compressiformis and Silurus burmanensis were not ascertained in this survey: the two species seem to be very rare or already extinct from the study area. ${ }^{16,17}$ In the present study, the three endemic species (Physoschistura shanensis, Systomus compressiformis and Silurus burmanensis) was not found in Inle Lake in 2016.

The community indicators described the fishermen increase in their participation in monitoring and restoration of fishery resources by expanding the protected area of the lake. The main economic activity of study area is fishing and floating garden/island cultivation. The tomato is the primary cash crop. Floating islands (swampy grassland accumulates organic matter and eventually mature to form solid floating island) are providing the spawning ground of fishes. The Kay La Village has more abundant floating cultivation in Inle Lake.

According to the results, Site I (Innla'e) and Site II (Kay La Village) were the highest level of phosphate that indicated undergoing eutrophication. In the Kay La Village and unregulated and increased using fertilizers in floating island cultivation, sedimentation results in increasing the nutrient uploading leading to Eutrophication in Inle Lake. In this study site, the endemic fish species were lower than the other sites. Phosphorus compounds are present in fertilizers and in many detergents. High concentrations of phosphorus compounds may cause a secondary problem in water bodies where algal growth is normally limited by phosphorus. ${ }^{18}$ This finding was agreement with the previous author.

Among the present study, the value of dissolve oxygen (DO) ranged from $4 \mathrm{mg} / \mathrm{L}$ to $4.5 \mathrm{mg} / \mathrm{L}$ and BOD ranged 2.5 to $3 \mathrm{mg} / \mathrm{L}$ during hot season. DO range 4 to $5 \mathrm{mg} / \mathrm{L}$ and BOD ranged $3-3.5 \mathrm{mg} / \mathrm{L}$ in rainy season. The value of DO ranged from 3.34 to $4.52 \mathrm{mg} / \mathrm{L}$ and the BOD value ranged from $2-8.6 \mathrm{mg} / \mathrm{L}$ in cold season. DO ranged was 0.6 to $8.5 \mathrm{mg} / \mathrm{L}$. More than half of the samples of Inle Lake are below the limits (DO $5.0-9.0 \mathrm{mg} / \mathrm{L}$ ) for fisheries and aquatic life according to the EU criterion. ${ }^{19}$ These severe conditions for aquatic life can lead to declines in the number of fish. The main cause of pollution is probably excessive human activity such as domestic uses, agriculture, recreation, tourism, fishing and aquaculture.

Inle Lake needs to be managed for water quality and biodiversity. The major problem suggested was eutrophication, and the data indicate the Lake is affected by human activities. The lower DO value indicated that the water quality is decreasing. The continued expansion of floating cultivation can increase the pollution through contamination of insecticides and chemical fertilizers. One of the reasons, the water quality in Inle Lake is poor because the problem of sedimentation was associated with the construction of floating cultivation. With respect to pollution and eutrophication within the Lake, it is important to immediately control of inputs of chemicals and sediments from within the lake and adjacent wetlands area. The results of this environment affect must be highlighted and knowledge share to the Inle (Intha) people. They should be educated in how to use organic insecticide and fertilizers instead of the chemicals.

The institutional indicators recorded the effective management of fishery resources through control of illegal fishing gears. In study area, fishermen used a lot of nets with various mesh size and used the electro fishing. Department of Fishery (DoF) prohibited operating small mesh size and electro fishing. During the present study, Innla $\mathrm{e}$ (center of the lake) and Kay La represented one of the most fishery productivity areas in Inle Lake. According to local fishermen, Tilapia is abundant in study area. Thus, indigenous fish species were disturbed by introduce species especially the productivity of Inle carp declining gradually declined. In the study area, fishermen are not commercial fishermen because their incomes are sufficient only for subsistence.

$\mathrm{FAO}^{20,21}$ described how to develop and use a sustainable development reference system (SDRS) as a coherent approach to selecting indicators, reference points and the framework within which to use them. Both the fisheries and aquaculture sector relate to the food production sectors that depend on a healthy ecosystem.

Therefore, there is an urgent requirement to appraise the status of local fishermen of Inle, and to safeguard the sustainability the remarkable array of native and endemic fish species and ornamental fishes. Not only to enjoy the eco-friendly nature of Inle Lake but also to maintain Inle Lake environmentally and friendly for the aquatic fauna and flora to thrive.

\section{Acknowledgements}

None.

\section{Conflict of interest}

Author declares that there is no conflict of interest.

\section{References}

1. Ohno T. Hito to Mizumi (People and the Lake), Kikan Minzokugaku. 1978;2(2):68-78.

2. Robinne F. Emergence of a Leading Group: A Case Study of the InterEthnic Relationships in Southern Shan State", in Michaud, Jean ed. Turbulent Times and Enduring Peoples: Mountain Minorities in the South-East Asian Massif Surrey: Cruzon; 2000. 
3. Takatani, Michio. Inle ko no Intha Zoku (Inle People in the Lake Inle) Kikan Minzokugaku. 1995;19(3):6-12.

4. NAPA. Myanmar: National Action Plan for Agriculture (NAPA) Working Paper 4: Fisheries and Aquaculture Food and Agriculture Organization of the United Nations; 2016.

5. Ramsar. The importance of wetlands ramsar.

6. FAO. Myanmar aquaculture and inland fisheries. Food and Agriculture Organization of the United Nations. Region Office for Asia and the Pacific. Bangkok: FAO \& NACA; 2003. 60 p.

7. Su M, Jassby AD. Inle: A Large Myanmar Lake in Transition, technical paper, Department of Environmental science and Policy, University of California, Davis California. USA: Lakes Reserv Res Manage; 2000:4954.

8. WHO. Water Quality Assessment: A Guide to Use of Biota, Sediment and Water in Environmental Monitoring. 2nd ed. WHO; 1992.

9. WHO. Guidelines for Drinking Water Quality, World Health Organization. $4^{\text {th }}$ ed. Switzerland; 2011.

10. Gulland JA. Fish Stock Assessment: A Manual of Basic Methods. New York: John Wiley and Sons; 1983.

11. Day F. The Fish of Indian being a Natural History of the Fishes Known to Inhabit the Sea and Freshwater of India, Burma and Ceylon, Vol. I and II. New Delhi: Today and Tomorrow's Book Agency; 1878. 776 p.

12. Talwar PK, Jhingran AG. Inland Fish of India and Adjacent Countries. Vol. I, II. New Dehli: Oxford and IBH Publishing Co. PVT. Ltd; 1991. $1158 \mathrm{p}$.
13. Jayaram KC. The Freshwater Fish of Indian Region. 2nd ed. Zoological Survey of India. 2013; 616 p.

14. Moe Nilar Tun. Diversity of Ornamental Fish Fauna and Water Quality of Inle Lake and Hopone Dam in Southern Shan State. PhD Dissertation, Department of Zoology. Myanmar: University of Mandalay; 2014. 139 p.

15. IUCN. IUCN Red List of Assessment. 2011.

16. Kano Y, Musikasithorn P, Iwata A, et al. A data set of fishes in and around Inle Lake, an ancient lake of Myanmar, with DNA barcoding, photo images and CT/3D models. Biodiversity data journal. 2016;4:e10539.

17. Annandale N. Fish of the Inle Lake. Record of the Indian Museum. Calcutta: Vol. XIV. The Indian Dictionary, Zoological survey of India; 1918. 64 p.

18. Bartram Jqq. Balance R. Water Quality Monitoring. A practice guide to the design and implementation of freshwater quality studies and monitoring programme. Great Briton: Chapman and Hall; 1996:95-106.

19. Akaishi F, Satake M, Otaki M. et al. Surface water quality and information about the environment surrounding Inle Lake in Myanmar. The Japan Society of Limnology. 2006;7(1):57-62.

20. FAO. The State of World Fisheries and Aquaculture. Meeting the sustainable development goals. Rome. Licence: CC BY-NC_SA 3.0 IGO; 2018 .

21. FAO. Indicators for Sustainable Development of Marine Culture Fisheries Food and Agriculture Organization of the United Nations. Rome; 2017. 